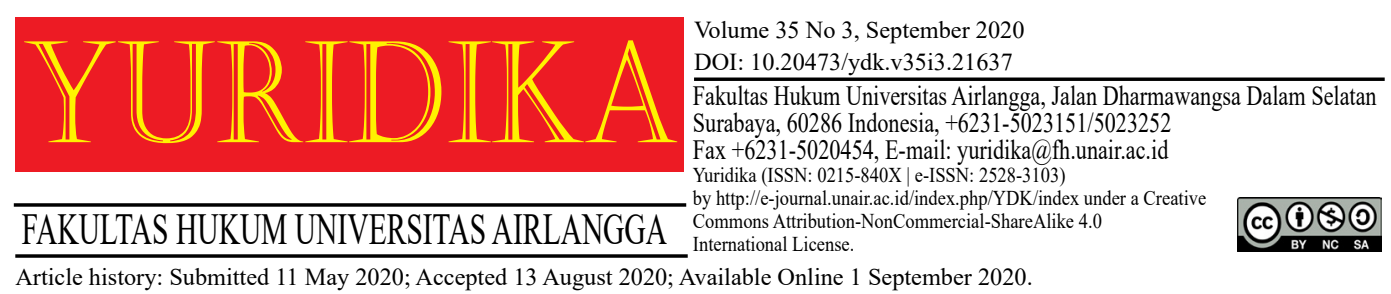

\title{
Implementation of the Law Principles of Good Corporate Governance in Indonesian Village-Owned Enterprise (BUMDes)
}

\author{
Sri Winarsi and Oemar Moechthar \\ sri.winarsi@fh.unair.ac.id \\ Universitas Airlangga
}

\begin{abstract}
Based on Law No. 6/2014 concerning Village in Indonesia, in order to increase the utilization of all economic potentials, economic institutions, as well as natural resources and human resources in an effort to improve welfare of the village communities, the village government can form village-owned enterprise (BUMDes). In its practice, implementation of the BUMDes management in several regions is not fully optimized, so that many cases of corruption were found. Thus, good governance practices are needed for optimizing the management of BUMDes to improve the livelihoods of the village. The methods used in this research is statute approach, conceptual approach, and case approach. The conclusions obtained in this research are directed to contribute to the concepts of strengthening the national law related to the management of BUMDes. Hopefully, it can strengthen the village's economy and reduce the level of corruption in Indonesia that is detrimental for the village.
\end{abstract}

Keywords: BUMDes; Villages; Good Corporate Governance.

\section{Introduction}

The Unitary State of the Republic of Indonesia/Negara Kesatuan Republik Indonesia (NKRI) is divided into provinces and then subdivided into regencies (kabupaten)/cities (kota). These are further subdivided into districts (kecamatan), and again into kelurahan and/or villages. The provinces and the regencies/cities each have their own regional government. Beside the status of the provinces as region, they are also administrative region which is the working area for the governor as the representative of the central government and in carrying out general government affairs in the territory. The regencies/cities are also administrative region which is the working area for regents/mayors in carrying out general government affairs in the territory. 
The course of government reform in Indonesia has caused shifts in the governance paradigm concerning the regional formation and community empowerment. This was motivated by the fact that Indonesia as a unitary state based on the principle of decentralization provides opportunities and flexibility for regions to carry out their regional autonomy. Regional autonomy - in response to the changing demands of a centralized state policy pattern and authoritarian government - is expected to empower the regions to be better optimized. Thus, the regional burdens and activities will be greater than the past. ${ }^{1}$

A change from centralization system to decentralization system have created space for regions to handle and to manage their households according to their respective characteristics. In other words, the regions can develop policy of the government system reforms in accordance with the socio-cultural conditions and aspirations of the people in the area. Constitutionally, these actions are in accordance with Article 18B of the Constitution of the Republic of Indonesia 1945 (UUD 1945). It is stated that the state recognizes and respects regional government units which are special in nature. The recognition and respect exist on condition that the adat/customary law community units and their traditional rights are still alive and in accordance with the community development and the principles of NKRI. ${ }^{2}$

In addition, in Article 18 (old) of UUD 1945 also stated that the implementation of decentralization must consider the socio-cultural diversity and the existence of indigenous government units, for instance Village and Nagari, which prior to the establishment of NKRI has been living as autonomous government based on adat law. ${ }^{3}$

Decentralization is the submission of government affairs by the central government to autonomous regions based on the principle of autonomy. In general, the concept of decentralization consists of two main perspectives,

\footnotetext{
1 Achmad Sodiki, Politik Hukum Agraria (Konstitusi Press 2013).[13].

2 Hengki Andora, 'Desa Sebagai Unit Pemerintahan Terendah Di Kota Pariaman' (2011) 2 Jurnal Ilmu Hukum.[20].

3 Philipus M Hadjon,[et.,al.], Pengantar Hukum Administrasi (Gadjah Mada University Press 2011).[111].
} 
namely: political perspective and administrative perspective. The fundamental difference between these two perspectives lies in the formulation of definitions and objectives of decentralization. In the political perspective, decentralization is defined as the devolution of power from the central government to regional government. Whereas in the administration perspective, the emphasis is on the objectives of decentralization, namely to emphasize more on the aspects of efficiency and effectiveness in government implementation and economic development in the region.

Based on these two perspectives, the term "original autonomy" has emerged, namely the authority of the village to regulate and manage its own household affairs, which is the origin of rights originating from customs and inherent since the formation of the village. ${ }^{4}$

In Article 1 Paragraph (1) of Law 6/2014 concerning Village, it is stated that:

"The village is a village and traditional village or called by other names, hereinafter called the Village, is a unit of community that has boundaries with the authority to regulate and manage the affairs of government, the interests of local community based on community initiatives, the right of the origin, and/ or the traditional rights recognized and respected in the system of government of the Republic of Indonesia".

Besides running the village governance, in Article 87 of Law No. 6/2014 mentioned that the Village can establish village-owned enterprise (BUMDes) in order to increase the Regional Original Income/Pendapatan Asli Daerah (PAD), which is managed by the family spirit and mutual cooperation. In the provisions of Article 1 Point 6 of Law No. 6/2014, it is stated that BUMDes is a business entity of all or most of the capital is owned by the village through direct participation from the wealth of the village separated in order to manage assets, services, and other businesses for the greatest welfare of the village community.

BUMDes can run its businesses in economic sector and/or public service sector in accordance with the provisions of the legislation. BUMDes is formed by

\footnotetext{
[140].

${ }^{4}$ Bayu Surianingrat, Pemerintahan Administrasi Desa dan Kelurahan (Rineka Cipta 1992).
} 
the village government to utilize all economic potentials, economic institutions, as well as the potential of natural resources and human resources in order to improve the welfare of the village community. Specifically, BUMDes can not be equated with legal entities such as limited liability company, Commanditaire Vennotschap (C.V.), or cooperative because BUMDes is a business entity characterized by the Village which aims to assist the implementation of the village government and to meet the needs of the village community.

In increasing the source of village income, BUMDes can collect savings at the local level of the village community, for instance through the management of revolving funds, savings, and loans. Moreover, BUMDes' activities are not only oriented to financial benefits, but also to support the improvement for the welfare of the village community. BUMDes is expected to develop business units in utilizing economic potentials. When business activities can run and develop properly, it is possible that BUMDes will follow the legal entity form established in the provisions of the legislation.

In this context, the establishment of BUMDes can be positioned as an effort to realize Nawacita, especially the first, third, fifth, and seventh agenda, with the following meanings: ${ }^{5}$ (1) regarding the first agenda of Nawacita, BUMDes is one of the policy strategies to present state institutions (the Ministry of Villages, Underdeveloped Regions, and Transmigration/Mendes PDTT) within the life of the community and the state in the Village; (2) regarding the third agenda, BUMDes is one of the policy strategies to build Indonesia from the periphery through the development of the village economic enterprises which are collective in nature; (3) regarding to the fifth agenda, BUMDes is one of the policy strategies to improve the quality of life of Indonesian people in the Village; and (4) regarding to the seventh agenda, BUMDes is one form of the village's economy independence by mobilizing strategic business units for the collective economic units of the Village. $[8-10]$.

${ }^{5}$ Bayu Surianingrat, Pemerintahan Administrasi Desa Dan Kelurahan (Rineka Cipta 1992). 
The BUMDes management is not an easy matter, many problematic cases which have occured - especially corruption cases-were due to a lack of understandings related to governance of the BUMDes management itself. As happened in the alleged corruption case in BUMDes Barakat Joint Save Four in Banjar District. There was an embezzlement of Social Assistance funds in the amount of Rp 113.241.000.00 (one hundred thirteen million and two hundred forty one thousand rupiahs) and the amount of Social Assistance funds was Rp 154.000.000.00 (one hundred fifty four million rupiahs). Likewise, in Trenggalek city, there was also an alleged corruption case in the Wonocoyo Village's BUMDes, which had caused state loss amounting to $\operatorname{Rp} 900.000 .000 .00$ (nine hundred million rupiahs).

For various cases that have occured, this research is conducted to find principles that can be applied in terms of governance of BUMDes. Consequently, these principles can support the efforts to improve empowerment of the village's economy and minimize the lack of knowledge and misuse of authority which has the potential to cause corruption.

\section{Method and Legal Grounds}

This research is legal research. Peter Mahmud Marzuki stated that in legal research, the results to be achieved are giving prescriptions about what is right. ${ }^{6}$ Thus, in this study, it will provide solutions to the legal issues that arose, which can provide inputs for the BUMDes management in order that they are in line with corporate governance in Indonesia. The approach used in this study is statute approach, namely an approach using legislations and regulations. ${ }^{7}$ Hereby, this approach is focused on the applicable laws and regulations. The approach by means of this is an attempt to analyze hierarchical relationships, consistency, and conformity between the authority of the Village in the BUMDes governance and other laws and regulations. In addition, this study also uses conceptual approach, namely an approach to build a concept that will be used as a reference in research

\footnotetext{
6 Peter Mahmud Marzuki, Penelitian Hukum (Prenada Media 2016).[89].

7 ibid.[97].
} 
derived from the views and doctrines which have been developed in law study. Moreover, this study is also conducted with case study approach, which analyzes and reviews cases related to the issues discussed.

\section{The Existence of BUMDes in the Context of Realizing the Improvement of the Village Community's Welfare}

Nowadays, the form of an individual business entity has begun to be abandoned and has shifted to a joint business entity and partnership. According to Clark in his book entitled "Corporate Law", the explanation is as follows:

"Only a few centuries ago, the privately owned, for profit business corporation did not exist. At the beginning of the nineteenth century, most business and commerce was conducted by proprietorships and partnerships. Today, however, the corporation is the dominant form of business organization. Corporations are overwhelmigly predominant, in terms of the percentage of receipts the account for, in manufacturing, transportation, public utilities, and wholesale trade. They clearly predominate, by margins of two to five, typically, in wholesale and resale trade and in services. However, they still account for only about a quarter of the receipts in agriculture, forestry, and fishing, where proprietorships are most important, and in certain large sectors of the economy, such as higher education and medical care, the nonprofit corporation is the dominant of organization".

Insociologystudy, humanare socialbeings, livingbeings whoareinterconnected with each other and in need of each other. Consciously or unconsciously, humans always maintain, nurture, and develop relationships between human. Hence, human live together in one place which can fulfill their needs. However, the conditions and the environment will affect the location of their dwellings, whether it is close to the beach, in the mountains, in the remote areas, or even on the water. ${ }^{9}$ The Village as a place to live together consists of various elements, including: (1) the nature of human as social beings; (2) psychological elements; (3) nature; (4) shared interests; and (5) external hazards.

8 Robert Charles Clark, Corporate Law (Little, Brown and Company 1986).[1-2].

9 Anom Surya Putra, Badan Usaha Milik Desa: Spirit Usaha Kolektif Desa (Kementerian Desa, Pembangunan Daerah Tertinggal, dan Transmigrasi Republik Indonesia 2015).[125-126]. 
The Village is the smallest unit of the country closest to the community and directly reaches the community's need for prosperity. As a country representative, the village must carry out development, both physical development and human resource development. This is an effort to improve the quality of life for the greatest welfare of the village community. ${ }^{10}$ Daeng Sudirwo mentioned that the village has the potentials as: (a) the last fortress of the implementation of Pancasila; (b) the centers of growth and improvement of mutual cooperation; (c) the source of all data, information, mobility, guidance, and supervision; (d) the center of growth and improvement of democratic souls; (e) the source of informal leadership; (f) the physical condition, $80 \%$ (eighty percent) of the Indonesian territory is rural areas; (g) the source of human power, $80 \%$ (eighty percent) of the Indonesian population is in the village; (h) the source of national security fostering; and (i) the source of natural potential. ${ }^{11}$ The implementation of the village government is a subsystem within the national government system, thus, the village has the authority to organize and to manage the interests of its people. The foundation of thinking in the regulation of Village Government is diversity, participation, real autonomy, and community empowerment.

The country's efforts to guarantee the survival of the Village can be seen through the legal products of the Village. From the history of the regulations, there is Law No. 22/1948 concerning Stipulation of Main Rules Regarding Self-Governance in Regions Eligible to Arrange and Maintain Their Own Affairs, Law No 1/1957 concerning Principles of Regional Government, Law No. 18/1965 concerning Principles of Regional Government, Law No. 19/1965 concerning Village as a Transitional Form to Accelerate the Realization of Level III Regions in the Entire Territory of the Republic of Indonesia, Law No. 5/1974 concerning Principles of Government in the Region, Law No. 5/1979 concerning Village Government,

\footnotetext{
${ }_{10}$ Maria Rosa Ratna Sri Anggraeni, 'Peranan Badan Usaha Milik Desa (BUMDES) Pada Kesejahteraan Masyarakat Pedesaan Studi Pada Bumdes Di Gunung Kidul Yogyakarta’ (2016) 28 Jurnal Modus.[156].

${ }^{11}$ Daeng Sudirwo, Pembahasan Pokok-Pokok Pemerintahan Di Daerah Dan Pemerintahan Desa (Penerbit Angkasa 1981).[43].
} 
Law No. 22/1999 concerning Regional Government, Law No. 32/2004 concerning Regional Government, Law No. 23/2014 concerning Regional Government, Law No. 9/2015 concerning Amendment to Law No. 23/2014 concerning Regional Government, and Law No 6/2014 concerning Village.

The presence of the Ministry of Villages, Underdeveloped Regions, and Transmigration has the mandate to execute Nawacita program in the Jokowi-JK government, particularly the third agenda "Building Indonesia from the edge by strengthening the regions and villages". One of the major agendas is to preserve the implementation of Law No. 6/2014 concerning Village systematically, consistently, and sustainably with facilities, supervision, and assistance. Village assistance is not merely about carrying out the mandate of Law No. 6/2014, but also important modalities to guard changes in the village in order to create an independent and innovative village. ${ }^{12}$ The Ministry of Villages, Underdeveloped Regions, and Transmigration is committed to realizing the expectations of the Law and Nawacita.

An effort which can be done is by boosting up the movement of the village's economy through village entrepreneurship. Furthermore, village entrepreneurship becomes a strategy in the development and growth of welfare. ${ }^{13}$ The village entrepreneurship can be accommodated in BUMDes developed by the government and the village community. In Indonesia, there are still many underdeveloped villages. Therefore, one of the strategies to mitigate this is to create village entrepreneurship in which resources and facilities are provided spontaneously by the village community to change the villages' social conditions.

The issuance of Law No 6/2014 and Government Regulation No. 47/2015 require the existence of independent and autonomous villages in the management of their resources. BUMDes is expected to play a role in improving the village's

\footnotetext{
12 Anom Surya Putra (n 9).[4].

13 B. Ansari,[et.,al.], 'Sustainable Entrepreneurship in Rural Areas' (2013) 5 Research Journal of Environmental and Earth Science.[26-31].
} 
economy. As revealed by Ngesti D. Prasetyo ${ }^{14}$ the existence of BUMDes is very strategic which in the end BUMDes serves as a driving force for the village's economy and the welfare of the village community. Hopefully, with the existence of BUMDes, the establishment of new businesses will root from the existing resources and optimization of existing economic activities of the village community. On the other hand, there will be an increase in employment opportunities in order to strengthen the village autonomy and to reduce unemployment. Data obtained from the Ministry of Villages of the Republic of Indonesia showed that in 2018 there are 74,957 villages in Indonesia which have as many as 32,249 BUMDes.

Village-owned enterprise (BUMDes) can not be equated with Regional-owned Enterprise (BUMD). BUMDes is a business entity managed by the community and village government. BUMDes is aimed to strengthen the village's economy and to build social cohesiveness of the community based on the needs and potentials of the village. BUMD is a business entity whose entire or part of its capital is owned by the region. With the regional autonomy to improve its economy, it can form its own BUMD, both for the purpose of public services and profit orientation, or a combination of both.

In the provisions of Article 3 of Permendagri No. 3/1998 concerning Legal Form of Regional-owned Enterprise, Form of Regional-owned Enterprise may be Regional Company or Limited Liability Company in Indonesia/Perseroan Terbatas (PT). BUMD which has the legal form of Regional Company, is subject to the applicable laws and regulations governing Regional Company. While BUMD whose legal form is Limited Liability Company, is subject to the Law concerning Limited Liability Company and to the Regulations for its implementation.

Each legal form of a business entity has its own characteristics. It is important to note in choosing the legal form of a business entity according to the purpose of

14 Ngesti D. Prasetyo, 2006, 'Sistem Pemerintahan Desa', Makalah, in Amelia Sri Kusuma Dewi, 'Peranan Badan Usaha Milik Desa (BUMDes) Sebagai Upaya Dalam Meningkatkan Pendapatan Asli Desa (PADes) Serta Menumbuhkan Perekonomian Desa' (2014) V Journal of Rural and Development.[1-2]. 
its formation. The formation of BUMD by regions is based on the potentials, the characteristics, and the needs of the region. ${ }^{15}$

As already explained, BUMDes is a business entity which is wholly or partly owned by the Village through direct participation derived from the wealth of the Village to manage assets, services, and other businesses for the greatest welfare of the village community. In the provisions of Law No.6/2014, the Village can establish BUMDes which are managed with the spirit of family and the mutual cooperation. BUMDes can run its business in economic sector and/or public service sector, not only oriented to financial benefits, but also to support the improvement of welfare. The results from the business process are used for the development of businesses and villages, the village community empowerment, and the provision of assistance to the poor through grants, social assistance, and revolving fund activities.

BUMDes represent the role of the village government in developing local economic potentials and in providing public services to the village community. As a unit of law community in Indonesia, the village has been placed as a mixed organization (hybrid) between self-governing community and local selfgovernment. The village government differs from the regional government. The village government is not identical with the organs of government and the head of village. It also includes both the local government and the elements of community, all of which form a unity of law. Moreover, the regional government does not contain the elements of community, but it only contains bureaucratic devices.

The village community through the village deliberation organ are actively involved in the process of: initiation, establishment (including the establishment of management organizations, business capital, and Articles of Association/Bylaws), and receival of progress reports at least twice a year. The village community is involved through a mechanism of citizen representations at the Village Consultative Body/Badan Permusyawaratan Desa in the establishment of Village Regulations

15 Dhimas Tetuko Kusumo, 'Kajian Yuridis Bentuk Hukum Badan Usaha Milik Daerah (BUMD) Di Bidang Perbankan Pasca Berlakunya Undang-Undang Nomor 23 Tahun 2014 Tentang Pemerintahan Daerah' (2016) IV Jurnal Prival Law.[22]. 
for the Formation of BUMDes and supervision of the responsibilities of the village government in guiding BUMDes.

\section{The BUMDes Governance in the Realization of Increasing Economic and Village Welfare}

Decentralization which occurred at the beginning of the Indonesian reform has smoothed and fostered the discourse of good governance. It becomes something fresh, popular, and spoken repeatedly by high officials to the lowest level in the area. No exception, the agendas of the movement also participated in the moderation and trust in good governance as a panacea for Indonesia's political-economic bureaucratic order. Academics and non-governmental organizations also expressed the discourse as a new icon which accompanied democratization. Since the reforms began, many study centers and good governance projects have been established and ordered through universities. From the issues which are closely related to legal reform, justice reform, decentralization, and budgeting, until the matter of legal drafting. Likewise, non-governmental organizations also participate by transmitting good governance ideas through issues that are not much different. ${ }^{16}$

The term of Good Governance is so often spoken but its meaning is rarely understood. Even the translation in Indonesian is still debatable. In Malaysia, for instance, Good Governance is translated into Penadbiran yang Baik. In Indonesia, the State Administration Institute (LAN) translates it as Kepemerintahan yang Baik. Good governance is a leading issue in the implementation of the state life, especially with the decreasing role of government as an institution which "running everything" and the increasing capability of the community in participating to manage their affairs together. The insistence that comes along with the increasing level of knowledge and competence of the community increasingly demands the government to organize governance that is not only clean, but also in accordance with the principles of Good Governance. The old patterns are no longer able to

\footnotetext{
${ }^{16}$ Herlambang P. Witratraman, 'Good Governance Dan Pembaruan Hukum Di Indonesia: Refleksi Dalam Penelitian Sosio-Legal' (2013) 2 Jurnal Hukum dan Peradilan.[26]
} 
respond to the interests of the community. Furthermore, good governance is the urgency from globalization. ${ }^{17}$

In fact, the concept of good governance comes from international institutions, such as the United Nations (UN), the International Monetary Fund (IMF), and the World Bank. The most widely used definition is the United Nations' version through the United Nations Development Program (UNDP) which defines good governance as: ${ }^{18}$

"The exercise of economic, political, and administrative authority to manage a country's affairs at all levels. Good governance comprises the existence of effective mechanisms, processes, and institutions through which citizens and groups articulate their interests, exercise their legal rights, meet their obligations, and mediate their differences".

Good Corporate Governance has several definitions according to some experts. According to the Forum for Corporate Governance in Indonesia (FCGI), Good Corporate Governance is a set of rules governing relationships between shareholders, managers of companies, creditors, government, employees, and other internal and external interests related to their rights and obligations or in other words a system that controls the company. The purpose of Good Corporate Governance is to create added value for stakeholders. ${ }^{19}$ According to the Organization of Economic Cooperation and Development (OECD), Good Corporate Governance is a set of relationships between a company's management, its board, its shareholders, and other stakeholders. Corporate Governance also implies the existence of a device structure to achieve goals and supervisions over performance. Good corporate governance can provide incentives for the board and management to achieve goals that put the company's interest ahead. Likewise, shareholders must facilitate effective supervisions in order to encourage companies to use more efficient resources. ${ }^{20}$

17 Zaenal Soedjais, 'Good Governance, Daya Saing Dan Investasi Global' (2003) 6 Jurnal Ilmu Sosial dan Ilmu Politik.[309].

18 ibid.[316].

${ }^{19}$ Lukas William Andypratama and Ronny H. Mustamu, 'Penerapan Prinsip-Prinsip Good Corporate Governance Pada Perusahaan Keluarga: Studi Deskriptif Pada Distributor Makanan' (2013) I Jurnal Agora.[2].

${ }^{20}$ Indra Surya and Ivan Yustiavandana, Penerapan Good Corporate Governance Mengesampingkan Hak-Hak Istimewa Demi Kelangsungan Usaha (Prenada Media Group 2006).[12]. 
The UNDP further specifies that good governance must contain a set of characteristics which must be met, namely participation, rule of law, transparency, responsiveness, consensus orientation, equality, effectiveness and efficiency, accountability, and strategic vision. Good governance is generally interpreted as a consensus reached by government, citizens, and private sectors in the administration of good and responsible government.

The principle of good corporate governance according to the OECD is a corporate control system, including the provision of assignments, rights and obligations of those with interests in the company, including shareholders, boards, managers, and stakeholders. Mariana Man and Maria Ciurea ${ }^{21}$ mentioned:

"Corporate governance has as main objective the transparency of share ownership. The existence of a transparent structure of ownership is necessary for shareholders so that one could evaluate to what extent they can influence the decision-making process and also for the fight against unfair transactions, especially against transactions between related parties or between those based on personal information, thereby protecting market integrity. In order to ensure equal access to information and, consequently, an equitable treatment for shareholders, all shareholders should simultaneously have access to the same information. Special accent should be put on the modern methods of information communication, which are effective methods to ensure the requirements and targets regarding information disclosure. The companies and all regulation bodies which receive information in accordance with the regulations in force have to ensure that the information is transmitted directly to the shareholders and to the public, in a fair and timely manner. The usual means of communication used by companies have to be clearly defined and agreed upon by those who finance the company, namely by the shareholders. It is important for the companies that seek to attract foreign capital to provide additional non-financial information to the market, which would help improve the image of corporate governance and would increase its market value. The decisive role lies within the Board of Directors who has to decide which information is relevant so that a domestic or foreign investor should objectively evaluate the financial-economic activity and the possible results in the near future. The corporate governance, as a complex system of management and control of the financialeconomic activity of the company, is seen as an information system which collects raw information,

\footnotetext{
${ }^{21}$ Maria Man and Maria Ciurea, 'Transparency of Accounting Information in Achieving Good Coorporate Governance. True View and Fair Value' (2016) 3 Social Sciences and Education Research Review.[41-62].
} 
processes it through the accounting department, and presents it to the decision making parties - managers and shareholders and other groups of interest. Still, the main feature of the financial-accounting information lies in obtaining the knowledge and skills needed to participate in some important economic decisions making at the company level".

A comprehensive and more contextualized view at the village-level is explained by Dwipayana and Eko, namely the mainstream of good governance discourse has emphasized three main points, which are country, civil society, and markets. ${ }^{22}$ Thus, governance mapping in the village consists of four main elements, namely (1) country (village government); (2) political community (The Village Consultative Body/Badan Perwakilan Rakyat); (3) civil society (institutions and social organizations); and (4) economic community (socio-economic organizations, arena of production and distribution carried out by perpetrators and village economic organizations). ${ }^{23}$

According to Syakhroza ${ }^{24}$ the enforcement of governance systems in companies from small to medium scale is influenced by two aspects of strength, namely: (1) internal strength, is a condition which supports the enforcement of governance. The internal strength consists of two aspects, (a) governance structure, namely the extent to which companies' activities are organized and coordinated responsibly in order to formulate policies to strengthen company's management. Governance structure includes two elements, namely organizational structure and company's business process; (b) governance mechanisms, namely mechanisms which rule governance that show rules of the game, procedures (Standard Operating Procedure/SOP), and relations between decision makers and those who exercise control over decisions. Governance mechanism includes elements, namely: corporate strategy, corporate policy, and SOPs. (2) external strength, is an external conditions of small and medium industries which influence the enforcement of

${ }^{22}$ Ari Dwipayana and Sutoro Eko, Membangun Good Governance Di Desa (IRE Press 2003).[24].

${ }^{23}$ Fajar Sidik, 'Menggali Potensi Lokal Mewujudkan Kemandirian Desa' (2015) 19 Jurnal Kebijakan dan Administrasi Publik.[115].

${ }^{24}$ Syakhroza, 'A. Teori Corporate Governance’ (2003) 08 Majalah Usahawan.[32]. 
governance systems which include three aspects of legal framework, government regulations, and business environment.

The main key to the need for good corporate governance is an effort to improve company's performance through a mechanism which monitors management's performance and to reinforce board of directors' and management's responsibility to stakeholders. ${ }^{25}$

The improvement of the village community's welfare is marked by the increase in the Regional Original Income/PAD which can be motivated by the establishment of strong BUMDes in accordance with the objectives and principles of social justice as the basic values of the state in Indonesia. Based on the previous experience, there is a possibility in the formation of a good institution, not necessarily being able to achieve its founding goals. This can be caused by a lack of managerial management and leadership in the institution. Therefore, the guidance provided by the regional government must also cover the management of BUMDes. ${ }^{26}$

In the era of free trade, competitiveness and competitive advantage are a key issue which makes a difficult challenge. Without the ability and high competitive advantage, Indonesian products will certainly not be able to penetrate in international markets, even the domestic market position will become a target of imported products. In other words, competitiveness is a determining factor in order to increase the trade volume and attract investment interest. Therefore, the efforts to improve and develop competitiveness can not be delayed anymore and should be a matter of concern to various parties, not only for business people but also for bureaucratic apparatus and organizations as well as other community members who become part of the work environment of business institutions. ${ }^{27}$

\footnotetext{
${ }_{25}$ Kevin Keasey, Corporate Governance: Economic, Management, and Financial Issues (Oxford University Press 1997).[76]

${ }^{26}$ Zulkarnain Ridlwan, 'Payung Hukum Pembentukan BUMDes' (2013) 7 Fiat Justitia Jurnal Ilmu Hukum.

${ }^{27}$ Eka Desy and M.S. Tumanggor, 'Strategi Pengelolaan Badan Usaha Milik Negara (BUMN) Dalam Upaya Menghadapi Era Globalisasi’ (2001) 9 Jurnal Mediatek.[36].
} 
BUMDes was established as a new approach in order to improve the village's economy. Management of BUMDes is fully implemented by village communities, namely from the village, by the village, and for the village. A key principle of BUMDes's work is by accommodating economic activities of the community in a form of institutions or business entities which are managed professionally, but still relying on the original potentials of the village. Furthermore, BUMDes can make the community's businesses to be more productive and effective. ${ }^{28}$

The Village is a leading government agent to achieve the national development goals, which can reach the actual target groups who want to be prospered. For instance, one of the way is by establishing a BUMDes in accordance with Permendagri No. 39/2010 concerning Village-owned Enterprise, which states that: "to improve the financial capacity of village government in government administration and increasing community's income through various economic activities of village communities, a village-owned enterprise is formed according to the needs and potentials of the village". BUMDes is established by village government whose capital ownership and management are undertaken by the village government and community. ${ }^{29}$

The existence of the Village as both a government institution and as an entity of a adat/customary law community unit is very important and strategic. As a government institution, the Village is the spearhead of service delivery to the community. Whereas as a legal entity unit, the village is a very solid base of the Indonesian people's system in order that it can be a strong foundation for the development of a stable and dynamic political, economic, socio-cultural, and land system. Thus, the Village is a miniature and a very good sample to observe the interaction between the government and community carefully. Through the

\footnotetext{
${ }^{28}$ Reza M. Zulkarnaen, 'Pengembangan Potensi Ekonomi Desa Melalui Badan Usaha Milik Desa (BUMDES) Pondok Salam Kabupaten Purwakarta’ (2016) 5 Dharmakarya: Jurnal Aplikasi Ipteks untuk Masyarakat.[1].

${ }^{29}$ Ramadana, Coristya Berlian. Heru Ribawanto, Suwondo, 'Keberadaan Badan Usaha Milik Desa (BUMDES) Sebagai Penguatan Ekonomi Desa' (2012) 1:6 Jurnal Administrasi Publik.[10681069].
} 
Village, BUMDes can be established by referring to village regulations based on regional regulations.

The village government's experience provides a lesson for management of village relations as a new approach which is expected to stimulate and drive the village's economy. The stimulus referred to is through the establishment of economic institutions which are fully managed by the village community. These economic institutions are no longer established on the basis of government instructions. They must be based on the wishes of the village community, which if managed properly have the potentials to generate demands in the market. Moreover, to ensure that the existence of these economic institutions is not controlled by certain groups which have large capital in the Village, the ownership of the institution belongs to the village and is jointly controlled. ${ }^{30}$

Indeed, the logic beneath the establishment of BUMDes is based on the village's needs and potentials as an effort to improve the community's welfare. In regards to the planning and establishment, BUMDes is built on the initiation of the community, and based on the principles of cooperation, participation, transparency, emancipation, accountability, and sustainability with memberbased mechanisms and independent nature. From all of these, the most important thing is the management of BUMDes must be carried out professionally and independently.

Fraud in financial statements is dangerous because it can cause: ${ }^{31}$ (a) a damage to the reliability, quality, materiality, and integrity of the financial reporting process; (b) a damage to integrity and objectivity of the audit professions, especially external auditors and internal auditors; (c) a reduction in trust to the capital market, as well as market share in financial reliability; (d) capital markets become less efficient; and (e) a reduction in the impact of economic growth and national prosperity.

\footnotetext{
${ }^{30}$ Zulkarnain Ridlwan, 'Urgensi Badan Usaha Milik Desa (BUMDes) Dalam Pembangun Perekonomian Desa' (2014) 8 Fiat Justisia Jurnal Ilmu Hukum.[426].

31 Michael K. Wells, Grantwriting Beyond the Basics, Book 2: Understanding Nonprofit Finances (Portland State University 2005).[22-25].
} 
One of the cause of fraud in financial statements is the possibility to manipulate company's low performance, low liquidity, and high level of debts. Thus, it will create pressure to company which also influences company's management to work harder in order to gain good performance. ${ }^{32}$

In terms of the BUMDes governance in the Miniterial Regulation of the Minister of Village, Underdeveloped Regions, and Transmigration Development No. 4/2015 concerning Establishment, Arrangement and Management, and Dissolution of Village-owned Enterprise, it does not explicitly mentioned about the principles which are used in the BUMDes management. This is feared to cause losses and also resulted in abuse of authority which ultimately leads to corruptions. Therefore, to avoid a legal vacuum, a rule graft can be realized by analyzing the principles of the BUMDes governance with the existing State-owned Enterprise/ BUMN or Regional Government-owned Enterprise/BUMD. Although between the two can not be equated, the related governance can refer to the existing principles of good corporate governance, including: (a) transparency; (b) independence; (c) accountability; (d) responsibility; and (e) fairness.

First, the principle of transparency means openness in implementing decisionmaking process and in disclosing material and relevant information regarding BUMDes. Second, the principle of independence is a condition in which BUMDes is managed professionally without conflict of interests and influences / pressures from any party which is not in accordance with the laws and regulations and healthy corporate principles. Third, the principle of accountability is the clarity of functions, implementation, and accountability of each organ (advisor, operational executor, supervisor) in BUMDes in order that company's management can carried out effectively. Fourth, the principle of responsibility is the compliance of BUMDes management with the laws and regulations and healthy corporate principles. Fifth, the principle of fairness is the compliance of the BUMDes management with the laws and regulations and healthy corporate principles.

32 Syamsudin, 'Tata Kelola Korporasi Dalam Mendeteksi Kecurangan Laporan Keuangan' (2017) 19 Daya Saing Jurnal Ekonomi Manajemen Sumber Daya.[64]. 
By applying these principles, the BUMDes organs can run the BUMDes governance in accordance with the existing path in order that the possibility of future losses can be minimized. Besides that, responsibility for the BUMDes organs to the Village can be accountable and directed because the organs have more structured provisions, especially in the BUMDes governance.

Seyadi mentioned about the role of BUMDes as follows: ${ }^{33}$ (a) to build and develop economic potentials and capabilities of the village community, in general to improve their economic and social welfare; (b) to assist actively in an effort to enhance the quality of human life and society; (c) to strengthen people's economy as a basis for the strength and resilience of the national economy with BUMDes as the foundation; (d) to realize and develop the economy of the village communities; (e) to help community to increase their income, thus they can benefit from the increase in income and prosperity of the community.

Compliance with the implementation of policies will not be realized if there is no support and participation from the village government institutions and community. The village government must have a good response to policy implementers. This can be done through evaluations which can have an impact on policy outcomes. Through evaluations, the government and the village can become a supervisor and assist in resolving the problems faced by managers of BUMDes. Thus, related to the policy outcomes, the compliance with the policy implementers has an influence on policy, in encouraging or realizing compliance from the BUMDes implementers or managers, a response or supervision is needed to be carried out by the village government.

\section{Conclusion}

The presence of BUMDes in the Village is expected to be able to stimulate and drive the economy in rural areas. This can be realized by implementing good governance in BUMDes. The BUMDes governance is carried out based on the principles of Good Corporate Governance which consist of transparency,

\footnotetext{
${ }^{33}$ Seyadi, BUMDes Sebagai Alternatif Lembaga Keuangan Desa (UPP STM YKPN 2003).[16].
} 
independence, accountability, and responsibility. By applying the principles of Good Corporate Governance in BUMDes, it can increase BUMDes' income which will contribute to the increase in the Regional Original Income/PAD. Consequently, the village's economy will increase and the village community will be more prosperous.

\section{Bibliography}

Achmad Sodiki, Politik Hukum Agraria (Konstitusi Press 2013).

Amelia Sri Kusuma Dewi, 'Peranan Badan Usaha Milik Desa (BUMDes) Sebagai Upaya Dalam Meningkatkan Pendapatan Asli Desa (PADes) Serta Menumbuhkan Perekonomian Desa' (2014) V Journal of Rural and Development.

Anom Surya Putra, Badan Usaha Milik Desa: Spirit Usaha Kolektif Desa (Kementerian Desa, Pembangunan Daerah Tertinggal, dan Transmigrasi Republik Indonesia 2015).

Ari Dwipayana and Sutoro Eko, Membangun Good Governance Di Desa (IRE Press 2003).

B. Ansari, [et.,al.], 'Sustainable Entrepreneurship in Rural Areas' (2013) 5 Research Journal of Environmental and Earth Science.

Bayu Surianingrat, Pemerintahan Administrasi Desa Dan Kelurahan (Rineka Cipta 1992).

Daeng Sudirwo, Pembahasan Pokok-Pokok Pemerintahan Di Daerah Dan Pemerintahan Desa (Penerbit Angkasa 1981).

Dhimas Tetuko Kusumo, 'Kajian Yuridis Bentuk Hukum Badan Usaha Milik Daerah (BUMD) Di Bidang Perbankan Pasca Berlakunya Undang-Undang Nomor 23 Tahun 2014 Tentang Pemerintahan Daerah' (2016) IV Jurnal Prival Law.

Eka Desy and M.S. Tumanggor, 'Strategi Pengelolaan Badan Usaha Milik Negara (BUMN) Dalam Upaya Menghadapi Era Globalisasi' (2001) 9 Jurnal Mediatek.

Fajar Sidik, 'Menggali Potensi Lokal Mewujudkan Kemandirian Desa' (2015) 19 Jurnal Kebijakan dan Administrasi Publik.

Hengki Andora, 'Desa Sebagai Unit Pemerintahan Terendah Di Kota Pariaman' 
(2011) 2 Jurnal Ilmu Hukum.

Herlambang P. Witratraman, 'Good Governance Dan Pembaruan Hukum Di Indonesia: Refleksi Dalam Penelitian Sosio-Legal' (2013) 2 Jurnal Hukum dan Peradilan.

Indra Surya and Ivan Yustiavandana, Penerapan Good Corporate Governance Mengesampingkan Hak-Hak Istimewa Demi Kelangsungan Usaha (Prenada Media Group 2006).

Kevin Keasey, Corporate Governance: Economic, Management, and Financial Issues (Oxford University Press 1997).

Lukas William Andypratama and Ronny H. Mustamu, 'Penerapan Prinsip-Prinsip Good Corporate Governance Pada Perusahaan Keluarga: Studi Deskriptif Pada Distributor Makanan' (2013) I Jurnal Agora.

Maria Man and Maria Ciurea, 'Transparency of Accounting Information in Achieving Good Coorporate Governance. True View and Fair Value' (2016) 3 Social Sciences and Education Research Review.

Maria Rosa Ratna Sri Anggraeni, 'Peranan Badan Usaha Milik Desa (BUMDES) Pada Kesejahteraan Masyarakat Pedesaan Studi Pada Bumdes Di Gunung Kidul Yogyakarta' (2016) 28 Jurnal Modus.

Michael K. Wells, Grantwriting Beyond the Basics, Book 2: Understanding Nonprofit Finances (Portland State University 2005).

Peter Mahmud Marzuki, Penelitian Hukum (Prenada Media 2016).

Philipus M Hadjon,[et.,al.], Pengantar Hukum Administrasi (Gadjah Mada University Press 2011).

Reza M. Zulkarnaen, 'Pengembangan Potensi Ekonomi Desa Melalui Badan Usaha Milik Desa (BUMDES) Pondok Salam Kabupaten Purwakarta’ (2016) 5 Dharmakarya: Jurnal Aplikasi Ipteks untuk Masyarakat.

Seyadi, BUMDes Sebagai Alternatif Lembaga Keuangan Desa (UPP STM YKPN 2003).

Syakhroza, ‘A. Teori Corporate Governance’ (2003) 08 Majalah Usahawan.

Syamsudin, 'Tata Kelola Korporasi Dalam Mendeteksi Kecurangan Laporan Keuangan' (2017) 19 Daya Saing Jurnal Ekonomi Manajemen Sumber Daya. 
Zaenal Soedjais, 'Good Governance, Daya Saing Dan Investasi Global' (2003) 6 Jurnal Ilmu Sosial dan Ilmu Politik.

Zulkarnain Ridlwan, 'Payung Hukum Pembentukan BUMDes'(2013) 7 Fiat Justitia Jurnal Ilmu Hukum.

_-, 'Urgensi Badan Usaha Milik Desa (BUMDes) Dalam Pembangun Perekonomian Desa' (2014) 8 Fiat Justisia Jurnal Ilmu Hukum.

HOW TO CITE: Sri Winarsi and Oemar Moechthar, 'Implementation of the Law Principles of Good Corporate Governance in Indonesian Village-Owned Enterprise (BUMDes)' (2020) 35 Yuridika. 